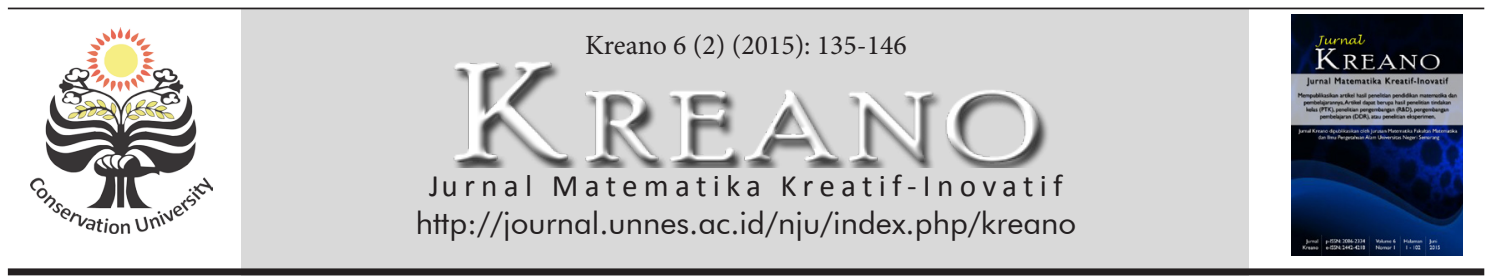

\title{
Desain Didaktis Penalaran Matematis untuk Mengatasi Kesulitan Belajar Siswa SMP pada Luas dan Volume Limas
}

\author{
Sulistiawati', Didi Suryadi², dan Siti Fatimah² \\ 'Program Studi Pendidikan Matematika STKIP Surya Tangerang \\ ${ }^{2}$ Program Studi Pendidikan Matematika Sekolah Pascasarjana (SPs) UPI Bandung \\ Email: sulistiawati@stkipsurya.ac.id \\ DOI: http://dx.doi.org/10.15294/kreano.v6i2.4833 \\ Received : October 2015; Accepted: November2015; Published: December 2015
}

\begin{abstract}
Abstrak
Penelitian ini dilatarbelakangi oleh rendahnya kemampuan penalaran matematis siswa SMP pada materi geometri. Metode penelitian yang digunakan adalah penelitian desain didaktis (didactial design research). Penelitian diawali dengan studi pendahuluan untuk mendapatkan data kesulitan belajar (learning obstacle) yang dilaksanakan di SMP Negeri 29 Bandung kelas IXE sebanyak 35 orang, SMA Negeri 1 Lembang kelas XI IPA2 sebanyak 41 orang, dan STKIP Siliwangi Bandung mahasiswa semester VI sebanyak 49 orang pada tahun pelajaran 2011/2012 semester genap. Selanjutnya, dikembangkan desain didaktis yang diujicobakan terbatas kepada 30 siswa kelas VIII B SMP Assalam Bandung. Dari uji coba terbatas dilakukan analisis untuk menyusun desain didaktis revisi. Hasil dari penelitian ini diantaranya perangkat pembelajaran yang digunakan pada pembelajaran sebelum menggunakan desain didaktis belum dapat menggali kemampuan penalaran matematis, desain didaktis penalaran matematis yang dikembangkan dapat memperkecil gap yang dihadapi siswa, dan siswa memberikan tanggapan positif terhadap desain didaktis yang dikembangkan.
\end{abstract}

\begin{abstract}
The background of this research was the lack of junior high school students' mathematical reasoning in geometry. This research used Didactical Design Research (DDR) method which started by a preliminary study to 35 students of grade IX E Public Junior High School 29 Bandung, 41 students of grade XI Science Program of Senior High School 1 Lembang, and 49 students of Siliwangi College of Education Bandung in semester VI for academic year 2011/2012. The preliminary study was aimed to explore students' learning obstacles to develep didactical design. The developed didactical design was implemented to 30 students of grade VII B of Assalam Junior High School Bandung. After this implementation the developed didactical design was revised. The results of this research were the learning tools used by previous teacher have not explored mathematical reasoning yet, the developed didactical design had minimized students' gaps, and students had positive response about the learning.
\end{abstract}

Keywoords: mathematical reasoning; didactical design research; learning obstacles; the surface area of pyramid; the volume of pyramid

\section{PENDAHULUAN}

Rendahnya kemampuan siswa SMP dalam memahami matematika menjadi masalah yang pelik di sekolah. Rendahnya pemahaman ini, salah satu penyebabnya adalah pembelajaran matematika lebih menekankan pada hal-hal yang prosedural dan mekanistik, pembelajaran berpusat pada guru, pembelajaran bersifat informatif, dan siswa menyelesaikan soal tanpa pemahaman yang mendalam (Herman, 2007). Akibat dari hal tersebut, kemampuan penalaran dan kompetensi strate- gis siswa kurang dapat berkembang sebagaimana mestinya.

Kenyataan di lapangan, secara umum menunjukkan bahwa metode mengajar yang digunakan guru lebih aktif dan siswa bersifat pasif. Hal ini sejalan dengan Sumarmo dan Permana (2007) yang menyatakan bahwa pada umumnya proses pembelajaran kurang mengoptimalkan aktivitas siswa sehingga siswa jarang aktif dalam pembelajaran.

Pada pembelajaran geometri ditemukan bahwa siswa mengalami kesulitan dalam 
belajar. Siswa mengalami kegagalan dalam memahami konsep-konsep kunci dalam geometri dan belajar geometri tanpa memahami terminologi dasar (Halat, 2008). Hal serupa juga diungkapkan oleh Burger dan Shaughnessy (1986) yang menyatakan bahwa siswa memiliki kesulitan dalam mengidentifikasi gambar dan kesulitan pada masalah pembuktian suatu teorema pada bangun dalam pembelajarn geometri. Selanjutnya, survey dari Programme for International Students Assessment (PISA) (2000) mengungkapkan bahwa siswa masih lemah dalam geometri, lebih khusus dalam pemahaman ruang dan bentuk.

Studi pendahuluan yang dilakukan oleh peneliti memberikan gambaran bahwa soalsoal penalaran matematis belum dikuasai oleh siswa (responden). Hal ini terlihat dari hasil bahwa siswa yang mampu menjawab soal yang diberikan dengan benar untuk siswa SMP Negeri 29 Bandung sebesar $15,4 \%$, siswa SMA Negeri 1 Lembang sebesar 36,6\%, dan mahasiswa STKIP Siliwangi sebesar $21,1 \%$. Rata-rata responden yang mampu menjawab soal-soal penalaran matematis berkaitan dengan luas dan volume limas dengan benar adalah sebesar $24,37 \%$.

Menurut Supriatna (2011) pengembangan desain didaktis mempunyai peranan dalam belajar matematika dan pembelajaran matematika. Peranan tersebut sangat berpengaruh terhadap bagaimana mereka melakukan pembelajaran di kelas (Suryadi, 2010). Bahkan pengembangan teori-teori baru diharapkan mampu menjawab hambatan-hambatan pembelajaran, lintasan belajar siswa dan karakteristik siswa. Pengembangan desain didaktis perlu terus dilakukan baik oleh guru, maupun peneliti.

Menurut Kansanen, terdapat dua aspek dasar dalam pembelajaran matematika, yaitu hubungan antara siswa dengan materi dan hubungan antara siswa dengan guru (lewat Suryadi, 2010). Hubungan guru dengan siswa disebut pedagogical relation (Hubungan Pedagogis/HP) sedangkan hubungan antara siswa dengan materi disebut dengan didactical relation (Hubungan Didaktis/ HD), yang biasa disajikan dalam segitiga didaktis. Lebih lanjut Suryadi (2010) menyatakan bahwa hubungan guru dengan materi tidak dapat diabaikan.
Menurut Suryadi (2010) HD dan HP tidak dapat dipandang secara parsial melainkan dapat terjadi secara bersamaan. Dalam hal ini, guru dapat merancang sebuah situasi didaktis dan membuat prediksi tanggapan siswa serta antisipasinya hingga tercipta situasi yang baru. Dengan demikian, dalam segitiga didaktis perlu ditambahkan hubungan antisipatis antara guru dan siswa, yang disebut dengan ADP (Antisipasi Didaktis Pedagosis).

Dalam segitiga didaktis guru berperan untuk menciptakan situasi didaktis (didactical situation) sehingga terjadi proses belajar dalam diri siswa. Hal ini mengindikasikan bahwa guru harus benar-benar menguasai materi ajar, pengetahuan tentang siswa, dan menciptakan situasi didaktis untuk mengoptimalkan pembelajaran. Hal ini selanjutnya dikenal dengan istilah relasi didaktis (didactical relation).

Situasi didaktis dan pedagogis merupakan sesuatu yang sangat kompleks, sehingga guru harus memiliki kemampuan yang dapat memandang hal tersebut secara komprehensif, dapat mengidentifikasi dan menganalisis hal-hal penting yang terjadi, dan melakukan tindakan yang tepat agar pembelajaran optimal. Kemampuan tersebut selanjutnya disebut sebagai metapedadidaktik.

Metapedadidaktik terdiri dari tiga komponen penting yaitu kesatuan, fleksibilitas, dan koherensi atau pertalian logis. Kesatuan maksudnya guru mampu memandang sisi-sisi segitiga didaktis yang dimodifikasi sebagai sesuatu yang utuh. Fleksibilitas adalah antisipasi yang sudah disiapkan oleh guru disesuaikan dengan didaktis dan pedagogis. Koherensi maksudnya situasi didaktis yang berkembang pada tiap milieu hingga muncul situasi yang berbeda-beda, maka perbedaan-perbedaan situasi tersebut harus dikelola sehingga perubahan situasi selama proses pembelajaran berjalan dengan lancar dan mengarah dalam pencapaian tujuan.

Di dalam didactical design research $(D D R)$, agar pengembangan situasi didaktis, analisis situasi belajar, dan pengambilan keputusan selama proses pembelajaran berlangsung dapat mendorong terjadinya situasi belajar yang optimal diperlukan upaya maksimal yang harus dilakukan sebelum pembelajaran. Upaya tersebut yang dikenal dengan 
ADP merupakan sintesis hasil pemikiran berdasarkan kemungkinan-kemungkanan yang diprediksikan dapat terjadi dalam proses pembelajaran.

Aspek yang harus dipertimbangkan dalam mengembangkan ADP adalah adanya kesulitan belajar (learning obstacle), terlebih lagi yang bersifat epistemologi (epistemological obstacle). Warkitri, dkk. (1990) mengemukakan kesulitan belajar adalah suatu gejala yang nampak pada siswa yang ditandai adanya hasil belajar rendah dibanding dengan prestasi yang dicapai sebelumnya. Jadi, kesulitan belajar itu merupakan suatu kondisi dalam proses belajar yang ditandai oleh adanya hambatan-hambatan tertentu dalam mencapai hasil belajar.

Kesulitan belajar disini adalah kesulitan belajar yang biasa dikenal dengan learning obstacle. Learning obstacle ada 3 jenis, yaitu ontogenical learning obstacle, didactical learning obstacle dan epistemological learning obstacle (Brousseau, 2002). Ontogenical learning obstacle adalah kesulitan belajar berdasarkan psikologis, dimana siswa mengalami kesulitan belajar karena faktor kesiapan mental, dalam hal ini cara berfikir siswa yang belum masuk karena faktor usia. Didactical learning obstacle adalah kesulitan belajar siswa terjadi karena kekeliruan penyajian, dalam hal ini bahan ajar yang digunakan siswa dalam belajar dapat menimbulkan miskonsepsi. Epistemological learning obstacle adalah kesulitan belajar siswa karena pemahaman siswa tentang sebuah konsep yang tidak lengkap, hanya dilihat dari asal-usulnya saja.
Penelitian ini bertujuan untuk mengetahui: 1) bagaimanakah perangkat pembelajaran yang digunakan guru pada pembelajaran sebelum pembelajaran dengan desain didaktis, 2) bagaimanakah desain didaktis untuk penalaran matematis pada materi luas dan volume limas, dan 3) bagaimana tanggapan siswa terhadap desain didaktis yang dikembangkan?

\section{METODE PENELITIAN}

Metode yang digunakan dalam penelitian ini adalah Penelitian Desain Didaktis (Didactical Design Research/ DDR). Menurut Suryadi (2011) DDR memikirkan secara komprehensif tentang apa yang disajikan, bagaimana kemungkinan tanggapan siswa, dan bagaimana mengantisipasinya. Proses berfikir ini dilakukan dalam 3 (tiga) fase pembelajaran, yaitu sebelum pembelajaran, pada saat pembelajaran, dan setelah pembelajaran. Proses berfikir guru pada tiga fase tersebut beserta hasil analisisnya berpotensi untuk menghasilkan desain didaktis inovatif.

Penelitian desain didaktis ini terdiri dari tiga tahapan, yaitu: (1) analisis situasi didaktis sebelum pembelajaran yang wujudnya berupa Desain Didaktis Hipotetis termasuk ADP, (2) analisis metapedadidaktik, dan (3) analisis retrosfektif yakni analisis yang mengaitkan hasil analisis situasi didaktis hipotesis dengan hasil analisis metapedadidaktik (Suryadi 2011). Dari ketiga tahapan tersebut akan diperoleh desain didaktis empirik yang tidak tertutup kemungkinan untuk terus disempurnakan melalui tiga tahapan DDR tersebut.

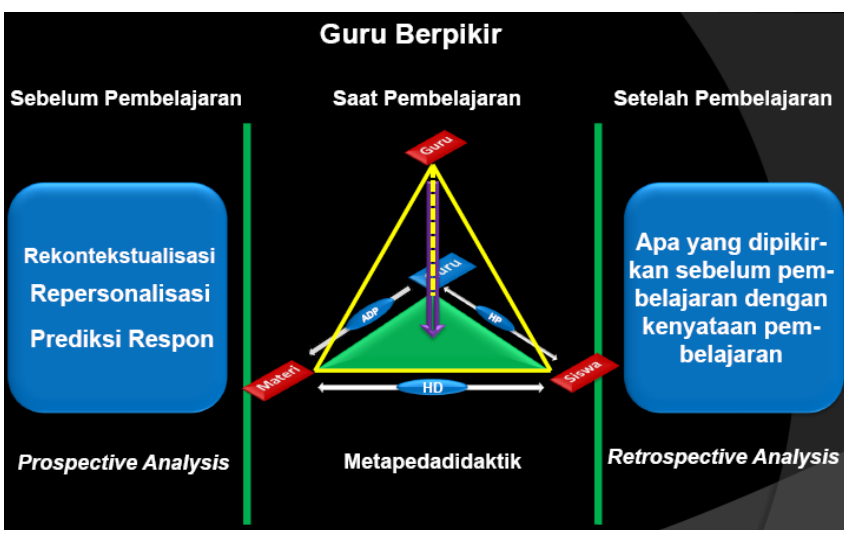

Gambar 1. Skema Didactical Design Research (DDR).

Sumber: Suryadi, 2010 
Tabel 1. Indikator dan Aspek Penalaran Matematis

\begin{tabular}{ll}
\hline \multicolumn{1}{c}{ Indikator Penalaran Matematis } & \multicolumn{1}{c}{ Aspek Penalaran Matematis } \\
\hline Memperkirakan jawaban dan proses & Siswa dapat menduga volume air di dalam kubus yang di \\
solusi & dalamnya dimasukkan piramida dengan ukuran tertentu. \\
Menganalisis pernyataan-pernyataan & Siswa dapat memeriksa jawaban atau pendapat atas per- \\
dan memberikan penjelasan/alasan & nyataan yang berkaitan dengan jaring-jaring limas. \\
yang dapat mendukung atau bertolak & Siswa dapat memeriksa pernyataan berkaitan dengan vol- \\
belakang & ume limas yang merupakan bagian dari limas yang lain. \\
Mempertimbangkan validitas dari & Siswa dapat merancang pola suatu masalah tertentu \\
argumen yang menggunakan berpikir & berdasarkan kondisi yang berkaitan dengan volume limas, \\
deduktif atau induktif & kemudian dapat menunjukkan bukti kebenaran dari jawa- \\
& ban yang diberikan. \\
& Siswa dapat menunjukkan bukti kebenaran/ketidakbenaran \\
& tentang selisih volume limas sebelum dan sesudah men- \\
& galami perpanjangan, jika panjang rusuk alas mengalami \\
Menggunakan data yang mendukung & Siswa dapat menyajikan alasan dari pernyataan tentang \\
untuk menjelaskan mengapa cara yang & kesamaan volume dari 3 buah limas yang diberikan. \\
digunakan serta jawaban adalah benar; & \\
dan memberikan penjelasan dengan & \\
menggunakan model, fakta, sifat-sifat, & \\
dan hubungan. & \\
\hline
\end{tabular}

Pada penelitian ini, yang akan menjadi fokus adalah pada tahap satu yaitu analisis situasi didaktis berupa hubungan didaktis (SiswaMateri) yang diungkap melalui penalaran matematis. Produk yang diharapkan pada penelitian ini berupa desain didaktis yaitu bahan ajar penalaran matematis pada materi luas dan volume limas. Gambaran tentang desain didaktis dapat dilihat pada gambar 1.

Penelitian ini diawali dengan studi pendahuluan untuk mendapatkan data tentang kesulitan belajar siswa dalam materi luas dan volume limas di tiga jenjang pendidikan yaitu SMP, SMA, dan PT. Studi pendahuluan ini dilaksanakan pada tahun pelajaran 2011/2012 semester genap di SMP Negeri 29 Bandung kelas IX E sebanyak 35 orang, di SMA Negeri 1 Lembang kelas XI IPA 2 sebanyak 41 orang, dan di STKIP Siliwangi Bandung mahasiswa semester 6 sebanyak 49 orang. Dari hasil analisis kesulitan belajar siswa inilah selanjutnya disusun desain didaktis bahan ajar yang mampu mengatasi kesulitan belajar siswa. Bahan ajar yang disusun selanjutnya diujicobakan secara terbatas pada subyek penelitian ini yaitu 30 siswa kelas VIII B SMP Assalam Bandung tahun pelajaran 2011/2012. Setelah selesai uji coba terbatas, dilakukan analisis untuk kemudian disusun bahan ajar revisi.
Instrumen dalam penelitian ini terdiri dari instrumen tes penalaran matematis, desain didaktis penalaran matematis, angket, dan lembar observasi. Instrumen tes penalaran matematis tentang materi luas dan volume ini merupakan instrumen yang sama yang digunakan pada saat studi pendahuluan yang sudah melalui tahap uji validitas, reliabilitas, daya pembeda, dan tingkat kesukaran. Desain didaktis penalaran matematis pada materi luas dan volume limas digunakan pada saat uji coba desain didaktis atau implementasi. Instrumen angket berisi tentang tanggapan siswa terkait dengan penggunaan desain didaktis selama pembelajaran. Lembar observasi digunakan untuk mengobservasi aktivitas guru dan siswa pada saat pembelajaran pada saat uji coba desain didaktis.

Dalam penelitian ini, indikator penalaran matematis yang digunakan untuk menyusun instrumen tes dapat dilihat pada Tabel 1.

Penskoran terhadap kemampuan penalaran matematis digunakan rubrik penilaian kemampuan penalaran matematis yang dikembangkan oleh Thompson (2006), dapat dilihat pada Tabel 2.

\section{HASIL DAN PEMBAHASAN}

Penelitian ini diawali dengan studi pendahu- 
Tabel 2. Kriteria Penilaian Penalaran Matematis

\begin{tabular}{ll}
\hline Skor & \multicolumn{1}{c}{ Kriteria } \\
\hline 4 & Jawaban secara substansi benar dan lengkap \\
3 & Jawaban memuat satu kesalahan atau kelalaian yang signifikan \\
2 & sebagian jawaban benar dengan satu atau lebih kesalahan atau kelalaian yang signifikan \\
1 & Sebagian besar jawaban tidak lengkap tetapi paling tidak memuat satu argumen yang benar \\
0 & Jawaban tidak benar berdasarkan proses atau argumen, atau tidak ada respon sama sekali \\
\hline
\end{tabular}

luan untuk mendapatkan data tentang kesulitan belajar (learning obstacle) pada siswa berkaitan dengan materi luas dan volume limas. Data tersebut diperoleh melalui soal tes diagnostik penalaran yang diberikan kepada siswa dan mahasiswa. Soal tes diagnostik ini sekaligus digunakan pada saat pengembangan desain didaktis di kelas uji coba. Sebelum digunakan, soal tes diagnostik ini perlu diujicobakan dan dianalisis untuk mengetahui validitas, reliabilitas, daya pembeda, dan tingkat kesukarannya.

Kesulitan belajar pada siswa yang ditemukan untuk tingkat SMP, SMA, dan PT memiliki rata-rata untuk tingkat SMP sebesar $84,57 \%$, tingkat SMA sebesar 63,41\%, dan tingkat PT sebesar 78,91\%. Persentase kesulitan belajar yang muncul ternyata masih cukup besar. Dengan demikian dapat simpulkan bahwa responden masih memiliki kesulitan belajar dalam kemampuan penalaran matematis pada materi luas dan volume limas.

\section{Observasi Perangkat Pembelajaran yang digunakan Guru}

Observasi ini dilakukan sebelum peneliti menyusun desain didaktis penalaran matematis berkaitan dengan luas dan volume limas. Pengamatan dilakukan pada perangkat pembelajaran yang telah digunakan guru pada proses pembelajaran luas dan volume limas pada pembelaaran sebelumnya. Perangkat pembelajaran yang diamati ada tiga jenis yaitu Rencana Pelaksanaan Pembelajaran (RPP), buku ajar (modul) dan Lembar Kerja Siswa (LKS). Berikut ini hasil pengamatan pada ketiga bahan tersebut.

\section{Observasi RPP}

Observasi dilakukan pada RPP pertemuan 3-4, pertemuan 7-8, dan pertemuan 13-14. Gambaran kegiatan di dalam RPP pada pertemuan 3-4, didahului dengan siswa diba- gi ke dalam kelompok-kelompok kecil yang beranggotakan 3-4 orang. Selanjutnya, guru memberikan apersepsi dengan mengingatkan kembali materi mengenai sifat segiempat dengan cara menyampaikan pertanyaan-pertanyaan tentang segiempat. Kemudian menyampaikan tujuan pembelajaran.

Pada kegiatan inti, siswa diberikan stimulus awal berupa penjelasan mengenai bangun ruang kubus dan balok dan meminta siswa memberikan contoh bangun ruang prisma dan limas dilingkungan sekitar. Kemudian siswa diminta berdiskusi dengan kelompoknya mengenai unsur-unsur prisma dan balok yang disajikan dalam LKS. Untuk siswa yang mengalami kesulitan diberikan bantuan oleh guru dan siswa lain yang berkemampuan lebih tinggi. Siswa mempresentasikan pekerjaan mereka di depan kelas sedangkan siswa lainnya menanggapi. Pada akhir kegiatan inti, guru mengajak siswa mendiskusikan materi yang telah dikerjakan dan hasil pekerjaan siswa dikumpulkan pada kumpulan portofolio.

Pada kegiatan penutup, guru mengulas kembali materi tentang unsur-unsur prisma dan limas. Kemudian memberikan pertanyaan-pertanyaan bimbingan untuk menguatkan pemahaman siswa. Guru juga memberikan kesempatan bertanya bagi siswa jika ada penjelasan yang belum dimengerti. Kegiatan yang serupa dilakukan untuk pertemuan 7-8 dan pertemuan 13-14.

Dari kajian RPP pada tiap pertemuan pembahasan materi limas (termasuk prisma di dalamnya) secara umum metode yang digunakan guru dalam pembelajaran adalah metode diskusi. Sebelum diskusi, guru memberikan stimulus berupa pertanyaan-pertanyaan bimbingan untuk memasuki materi selanjutnya. Selain itu, guru juga memberikan latihan soal-soal penugasan. Guru menggunakan alat peraga berupa prisma dan limas untuk menentukan jaring-jaring kedua ban- 
gun tersebut, menggunakan media LCD proyektor untuk menampilkan slide powerpoint berkaitan dengan luas limas.

\section{Observasi Bahan Ajar}

Bahan ajar yang digunakan adalah buku sekolah elektronik dengan judul Matematika Konsep dan Aplikasinya untuk kelas VIII SMP dan MTs yang diterbitkan pusat perbukuan Depdiknas tahun 2008, bab 9 tentang Bangun Ruang Sisi Datar Limas dan Prisma Tegak. Urutan penyajian materi adalah 1) bangun ruang prisma dan limas (prisma dan limas), 2) diagonal bidang, diagonal ruang, serta bidang diagonal prisma dan limas, 3) Jaring-jaring prisma dan limas, dan 4) Luas prisma dan limas (luas prisma, luas limas, volume prisma dan limas)

\section{OBSERVASI LKS}

Berikut ini adalah gambaran LKS yang diberikan kepada siswa pada pembelajaran materi limas.

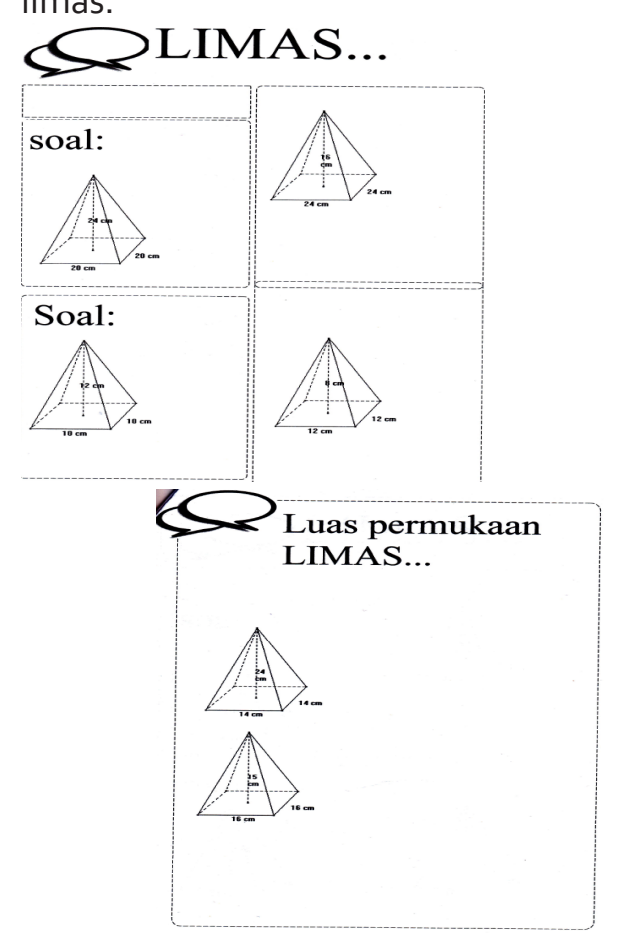

Gambar 2. Lembar Kerja Siswa (LKS) tentang Limas dan Luas Limas

Dari gambaran LKS di atas, soal yang diberikan kepada siswa hanya sejenis yaitu limas segiempat. Siswa diminta untuk menghitung luas dan volume limas dengan unsur-unsur yang telah diketahui. Dalam kasus seperti ini siswa tinggal menggunakan rumus luas dan volume limas, mensubstitusikan panjang unsur-unsur limas yang diberikan kemudian menghitungnya. Untuk persoalan seperti di atas, jika siswa dapat menyelesaikan jawaban dengan benar maka siswa telah memiliki kemampuan pemahaman matematis yang baik, sedangkan kemampuan penalaran matematis belum dapat tergali.

\section{Pengembangan Desain Didaktis Penal- aran Matematis}

Desain didaktis yang dikembangkan melibatkan tiga komponen, yaitu prospective analysis, fleksibilitas, dan koherensi atau pertalian logis. Penjelasan untuk ketiga komponen desain didaktis tersebut adalah:

\section{Prospective Analysis}

Prosepective Analysis adalah proses berpikir guru tentang skenario pembelajaran yang akan dilaksanakan. Prosepective Analysis ini diterapkan dalam bagaimana guru membuat skenario pembelajaran terkait penalaran matematis pada luas dan volume limas. Sebelum pembelajaran berlangsung guru harus dapat memprediksikan respon siswa akibat tindakan didaktis yang diberikan, salah satunya dapat berupa prediksi mengenai kemampuan prasyarat siswa sebelum siswa belajar limas. Siswa harus memahami materi prasyarat berupa luas segitiga, luas bangun datar, luas poligon, luas bangun kubus dan prisma, dan volume kubus dan prisma. Pemahaman tentang materi prasyarat ini diharapkan dapat mempermudah proses pembelajaran limas yang berlangsung.

Skenario yang di rancang guru menyajikan: 1) konsep limas (definisi, unsur-unsur, dan jaring-jaring limas) dan mengidentifikasi alas dan tinggi limas, 2) menentukan luas limas, dan 3) menentukan volume limas. Skenario yang pertama berkaitan dengan konsep limas, alas, dan tinggi limas. Respon yang muncul adalah siswa kurang mampu mengkomunikasikan definisi limas meskipun secara pemahaman mereka sudah paham. Peran guru di sini mengarahkan siswa melalui diskusi interaktif bagaimana membuat definisi limas dengan mengidentifikasi bidang-bidang yang membatasinya dan ciri khas yang dimi- 
liki oleh bangun limas. Pemahaman tentang definisi limas sudah dimiliki siswa sehingga dalam menentukan unsur-unsur limas siswa tidak menemui kesulitan, demikian juga untuk alas dan tinggi limas.

Skenario kedua berkaitan dengan luas limas adalah guru menyajikan masalah bangun kubus yang memuat prisma. Guru meminta siswa untuk mengidentifikasi bangun prisma yang terbentuk kemudian menentukan rumus luas pernuakannya. Siswa diminta berdiskusi kemudian menentukan rumus luas prisma yang terbentuk. Proses ini dilakukan guru bertujuan untuk menstimulasi proses bernalar siswa terkait dengan materi yang pernah dipelajari sebelumnya. Selanjutnya, cara berpikir siswa seperti ini dapat digunakan untuk menyelesaikan soal-soal penalaran matematis terkait luas dan volume limas. Prediksi yang muncul dalam menyelesaikan kasus ini adalah siswa masih bingung dalam mengidentifikasi prisma yang terbentuk dan menentukan sisi/bidang yang membatasinya. Akibatnya siswa juga akan bermasalah dalam menentukan rumus luas prisma yang diminta.

Setelah masalah yang diberikan dapat dipahami oleh siswa selanjutnya adalah siswa diajak menentukan luas limas. Pemahaman tentang jaring-jaring limas telah dimiliki oleh siswa sehingga siswa dalam menentukan luas limas dapat mengubah bangun limas menjadi jaring-jaring terlebih dahulu. Prediksi yang muncul, siswa dapat memperkirakan untuk memperoleh luas limas dengan menjumlahkan luas bangun-bangun datar yang terdapat pada jaring-jaring limas. Limas yang diberikan mulai limas segitiga, limas segiempat, dan limas yang terbentuk dari bangun prisma.

Skenario ketiga berkaitan dengan menentukan volume limas. Pada saat siswa menentukan rumus volume limas diberikan pemahaman bahwa volume limas dapat diperoleh dari volume kubus di bagi enam atau volume prisma dibagi tiga. Dalam pembelajaran ini siswa diminta mendiskusikan bagaimana melihat limas yang terbentuk dari perpotongan-perpotongan diagonal ruang kubus. Siswa dapat memahami dengan baik tentang limas yang terbentuk merupakan bagian kubus besarnya sama namun siswa sulit dalam mengkomunikasikan secara tertulis bagaimana mendapatkan volume limas dari volume kubus. Beda halnya yang terjadi pada saat menentukan volume limas yang merupakan volume prisma dibagi tiga. Secara konsep siswa tahu bahwa untuk meilhat ketiga limas yang terbentuk dapat dikatakan sama maka haruslah luas alas dan tinggi ketiga limas sama. Akan tetapi, kemampuan komunikasi siswa secara tertulis belum dimiliki sehingga peran guru dalam mengarahkan siswa menemukan rumus volume limas ini sangat besar.

Pada setiap akhir pembelajaran guru memberikan latihan soal untuk dikerjakan di rumah dengan harapan siswa dapat memperkuat kemampuan penalaran mereka tentang soal-soal penalaran matematis berkaitan dengan limas. Dalam latihan soal ini diharapkan siswa dapat membangun pengetahuannya dalam soal-soal penalaran matematis.

\section{Fleksibilitas}

Fleksibilitas adalah prediksi dan antisipasi yang sudah disiapkan oleh guru disesuaikan dengan didaktis dan pedagogis. Prediksi respon dan antisipasinya adalah sebuah rencana yang belum tentu sesuai dengan kenyataan yang muncul. Apabila kejadian ini terjadi guru telah mempersiapkan skenario yang baru sesuai dengan pembelajaran pada saat itu. Menurut Suryadi (2008), jika respon yang muncul tidak sesuai dengan prediksi maka antisipasi yang sudah dipersiapkan perlu dimodifikasi sepanjang proses pembelajaran sesuai dengan kenyataan yang ada.

Pembelajaran tentang limas yang telah dilaksanakan juga mengalami penyimpangan dari rencana semula. Hal ini lebih kepada waktu yang banyak habis dalam mendiskusikan masalah luas prisma yang termuat oleh kubus, sehingga berakibat waktu untuk bagian yang lain menjadi lebih sedikit. Oleh karena itu, rencana awal dimana siswa mendiskusikan cara mengkonstruksi luas limas dari limas segitiga, limas segiempat, dan limas yang termuat dalam prisma menjadi berubah. Guru meminta siswa untuk mendiskusikan cara mengkonstruksi limas segitiga, dan untuk limas segiempat dicoba secara mandiri diluar jam pembelajaran, kemudian untuk limas yang termuat di dalam prisma guru yang 
mengambil kendali kelas dan menjelaskan kepada siswa melalui media LCD dan papan tulis. Dengan langkah yang diambil ini pembelajaran dapat berlangsung dengan baik.

\section{Koherensi atau Pertalian Logis}

Koherensi memiliki maksud bahwa situasi didaktis yang berkembang pada tiap milieu hingga muncul situasi yang berbeda-beda, maka perbedaan-perbedaan situasi tersebut harus dikelola sehingga perubahan situasi selama proses pembelajaran berjalan dengan lancar dan mengarah dalam pencapaian tujuan. Situasi didaktis yang muncul memang tidak sesuai dengan rencana (prediksi dan antisipasi) namun guru tetap membimbing siswa dalam perubahan situasi tersebut untuk mendapatkan tujuan pembelajaran yang direncanakan. Sebagai contoh, siswa mendiskusikan cara mengkonstruksi luas limas dari limas segitiga, limas segiempat, dan limas yang termuat dalam prisma menjadi berubah. Guru meminta siswa untuk mendiskusikan cara mengkonstruksi limas segitiga, dan untuk limas segiempat dicoba secara mandiri diluar jam pembelajaran, kemudian untuk limas yang termuat di dalam prisma guru yang mengambil kendali kelas dan menjelaskan kepada siswa melalui media LCD dan papan tulis.Kejadian tersebut juga dilakukan dalam penyelesaian soal-soal latihan. Beberapa siswa memiliki perbedaan cara berpikir dalam menjawab soal dan guru mengelola kejadiankejadian ini selama mengarah pada proses yang benar.

Rencana pembelajaran dan pelaksanaan pembelajaran pada umumnya telah berjalan dengan baik. Selanjutnya adalah analisis setelah pembelajaram yang dapat dilihat melalui hasil tes penalaran matematis siswa, observasi, dan wawancara. Hasil tes yang diberikan pada siswa SMP Assalam kelas VIII B nampak bahwa semua siswa berusaha menjawab semua nomor dengan sebaik-baiknya. Namun persentase siswa yang memiliki kesulitan dalam memberikan jawaban benar masih banyak yang di bawah 50\%, meskipun jika dibandingkan dengan studi pendahuluan persentase siswa yang mengalami kesulitan menurun. Hal ini muncul untuk soal nomor 3 langkah ke-2 dari 2 langkah jawaban, nomor 4

Tabel 3. Perbandingan Persentase Kesulitan Jawaban Siswa

\begin{tabular}{|c|c|c|c|c|c|}
\hline \multirow{3}{*}{ No. Soal } & \multirow{3}{*}{ Langkah } & \multicolumn{4}{|c|}{ Persentase Jawaban Siswa (\%) } \\
\hline & & \multicolumn{2}{|c|}{ Studi Pendahuluan } & \multicolumn{2}{|c|}{ Kelas Uji Coba } \\
\hline & & LS & LB & LS & LB \\
\hline \multirow{2}{*}{1} & 1 & 73,40 & 26,60 & 16,67 & 83,33 \\
\hline & 2 & 79,52 & 20,48 & 40,00 & 60,00 \\
\hline \multirow{2}{*}{2} & 1 & 8,70 & 91,30 & 0,00 & 100,00 \\
\hline & 2 & 12,64 & 87,36 & 3,33 & 96,67 \\
\hline \multirow{2}{*}{3} & 1 & 97,15 & 2,85 & 36,67 & 63,33 \\
\hline & 2 & 97,15 & 2,85 & 80,00 & 20,00 \\
\hline \multirow{3}{*}{4} & 1 & 67,84 & 32,16 & 40,00 & 60,00 \\
\hline & 2 & 70,56 & 29,44 & 40,00 & 60,00 \\
\hline & 3 & 99,32 & 0,68 & 93,33 & 6,67 \\
\hline \multirow{3}{*}{5} & 1 & 62,13 & 37,87 & 20,00 & 80,00 \\
\hline & 2 & 76,80 & 23,20 & 86,67 & 13,33 \\
\hline & 3 & 92,53 & 7,47 & 86,67 & 13,33 \\
\hline \multirow{3}{*}{6} & 1 & 96,75 & 3,25 & 76,67 & 23,33 \\
\hline & 2 & 100,00 & 0,00 & 70,00 & 30,00 \\
\hline & 3 & 100,00 & 0,00 & 86,67 & 13,33 \\
\hline \multicolumn{2}{|c|}{ Rata-rata } & 75,63 & 24,37 & 51,78 & 48,22 \\
\hline
\end{tabular}

Keterangan:

LS = langkah jawaban salah, LB = langkah jawaban benar 


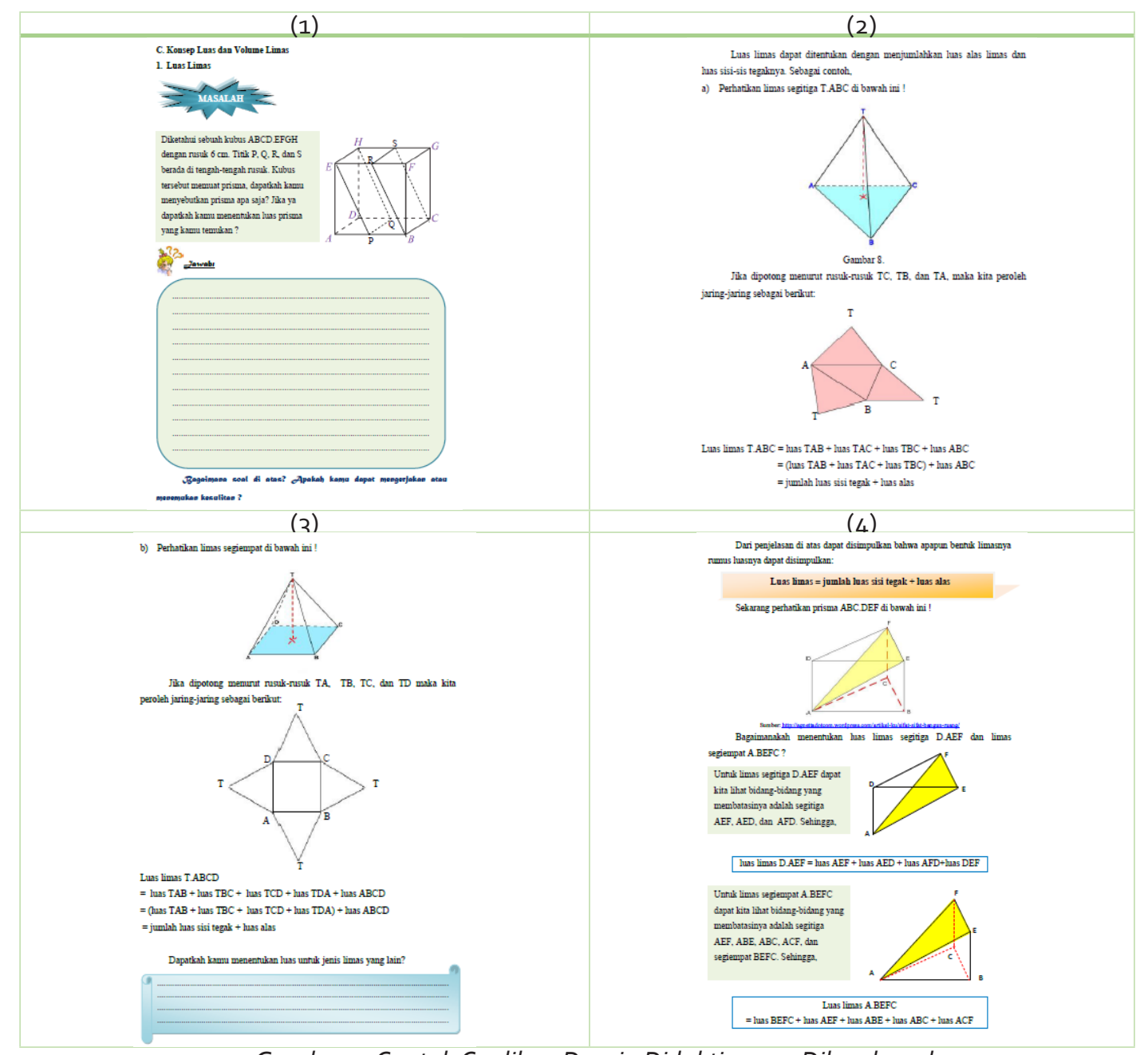

Gambar 3. Contoh Cuplikan Desain Didaktis yang Dikembangkan

langkah ke-3 dari 3 langkah jawaban, nomor 5 langkah ke-2 dan ke-3 dari 3 langkah jawaban, dan soal nomor 6 untuk ketiga langkah dari 3 langkah jawaban. Hal ini tampak pada Tabel 3.

Dari tabel di atas terlihat bahwa ratarata kesulitan belajar pada kelas uji coba ini sebesar $51,78 \%$ sedangkan studi pendahuluan $75,63 \%$. Persentase kesulitan ini masih tergolong tinggi yang berarti siswa masih memiliki kesulitan, penyebabnya adalah siswa jarang berlatih soal-soal yang memuat kemampuan penalaran matematis. Selain latihan soal yang diberikan guru jumlahnya terbatas sehingga pengalaman yang dimiliki siswa masih sangat sedikit. Hal ini berakibat jika diberikan soal dalam konteks lain siswa cukup merasa bingung.

Selisih persentase ini sebesar $23,85 \%$ yang dapat kita katakan cukup baik mengingat implementasi ini baru implementasi pertama. Namun kesulitan belajar yang muncul masih lebih dari lebih 50\%, oleh karena itu bahan ajar yang telah disusun perlu di revisi. Dari analisis kesulitan yang mucul, tanggapan siswa, dan observasi terhadap proses pembelajaran di susunlah desain didaktis revisi.

Berikut ini salah satu cuplikan dari desain didaktis pada topik konsep luas limas. Pada awal pembelajaran konsep luas limas, disajikan sebuah masalah yang berkaitan dengan kemampuan penalaran matematis untuk materi yang sudah pernah siswa dapat sebelumnya, seperti tampak pada Gambar 3.

\section{Tanggapan Siswa Terhadap Desain Didaktis yang Dikembangkan}

Tanggapan (respon) siswa terhadap penggunaan desain didaktis penalaran matematis dikembangkan dengan mengikuti indikator tanggapan siswa. Penskoran menggunakan skala Likert dengan kriteria sangat 
Tabel 4. Indikator Tanggapan Siswa

\begin{tabular}{cll}
\hline No. & \multicolumn{1}{c}{ Aspek } & \multicolumn{1}{c}{ Indikator } \\
\hline 1. & Sikap siswa terhadap & Menunjukkan ketertarikan terhadap penyampaian pelajaran \\
pembelajaran & $\begin{array}{l}\text { Menunjukkan keaktifan di dalam kelas } \\
\text { Menunjukkan ketertarikan terhadap metode yang digunakan }\end{array}$ \\
2. & $\begin{array}{l}\text { Sikap siswa terhadap } \\
\text { bahan ajar yang digu- }\end{array}$ & $\begin{array}{l}\text { Menunjukkan ketertarikan terhadap bahan ajar yang digunakan } \\
\text { nakan }\end{array}$ \\
3. & $\begin{array}{l}\text { Sikap siswa terhadap } \\
\text { soal-soal evaluasi }\end{array}$ & Memiliki ketertarikan terhadap latihan soal yang disajikan dalam bahan \\
\hline
\end{tabular}

tidak setuju (STS) skor 1 , tidak setuju (TS) skor 2, setuju (S) skor 3, sangat setuju (SS) skor 4 untuk tipe pertanyaan positif demikian berlaku sebaliknya untuk tipe soal negatif. Indikator tanggapan siswa dapat dilihat pada tabel 4 .

Berdasarkan hasil analisis angket tanggapan tentang pembelajaran yang menggunakan desain didaktis, terlihat siswa memiliki tanggapan yang baik. Hal tampak pada skor tanggapan yang diberikan kepada siswa, diperoleh persentase skor adalah $62,24 \%$ yang berarti pengembangan desain didaktis mendukung dalam pembelajaran.

Baiknya tanggapan siswa juga didukung oleh berkurangnya kesulitan siswa dalam menyelesaikan tes penalaran matematis yang diberikan. Berdasarkan pengamatan siswa aktif dalam menyampaikan aspirasi dan bertanya pada guru ataupun teman kelas. Bahkan beberapa siswa dapat memunculkan jawaban yang dengan cara yang berbeda dari jawaban guru. Hal ini menunjukkan siswa mampu memunculkan kemampuan bernalar yang baik setelah diberikan pembelajaran dengan desain didaktis. Selain itu, siswa menjadi lebih tertarik dalam menyelesaikan masalah yang diberikan guru dengan bekerjasama temantemannya.

Pembelajaran dengan menggunakan desain didaktis yang dikembangkan menjadikan respon siswa terhadap pembelajaran lebih positif. Siswa mampu memunculkan kemampuan penalaran dalam menyelesaikan soal-soal yang diberikan guru.

\section{TEMUAN}

Pertemuan ke-1

Pertemuan ini mengajarkan konsep limas, alas limas, dan tinggi limas. Secara umum, pembelajaran berlangsung sesuai RPP. Guru membagi kelas menjadi kelompok-kelompok kecil terdiri dari 3-4 orang, harapannya siswa dapat mendiskusikan materi dan memunculkan ide-ide untuk memahami permasalahan yang ditampilkan dalam LKS. Saat berdiskusi guru berkeliling kelas dan memberikan scaffolding bagi yang memerlukan. Siswa tampak memperhatikan, namun kurang begitu aktif dalam kerjasama kelompok dan lebih individual.

Di sisi lain, siswa lebih banyak bertanya kepada guru langsung untuk hal yang kurang mereka pahami. Proses ini cukup memakan banyak waktu, sehingga pada bagian siswa mendiskusikan contoh soal menjadi berkurang. Oleh karena itu, contoh soal yang seharusnya di bahas oleh siswa dijadikan PR untuk di bahas pada pertemuan selanjutnya.

\section{Pertemuan ke-2}

Pertemuan ini mempelajari tentang luas limas, diawali dengan guru memberikan masalah tentang luas beberapa bangun prisma pada sebuah kubus yang memuat kemampuan penalaran matematis. Soal yang diberikan adalah siswa diminta melihat prisma yang ada dalam kubus $A B C D$.EFGH dengan rusuk $6 \mathrm{~cm}$, dan titik-titik $P, Q, R$, dan $S$ berturut-turut berada di tengah-tengah rusuk $A B, D C, E F$, dan $H G$, dapat dilihat pada Gambar 4 .

Kebanyakan siswa mengalami kesulitan dalam mengidentifikasi prisma yang terbentuk, sehingga diskusi kelompok kurang berjalan dengan baik. Guru memberikan scaffolding untuk beberapa kelompok selanjutnya melakukan pembahasan di depan kelas meIalui $L C D$ dan papan tulis. Untuk menentukan luas siswa juga mengalami kesulitan terutama untuk menentukan panjangnya sisi seperti EP 


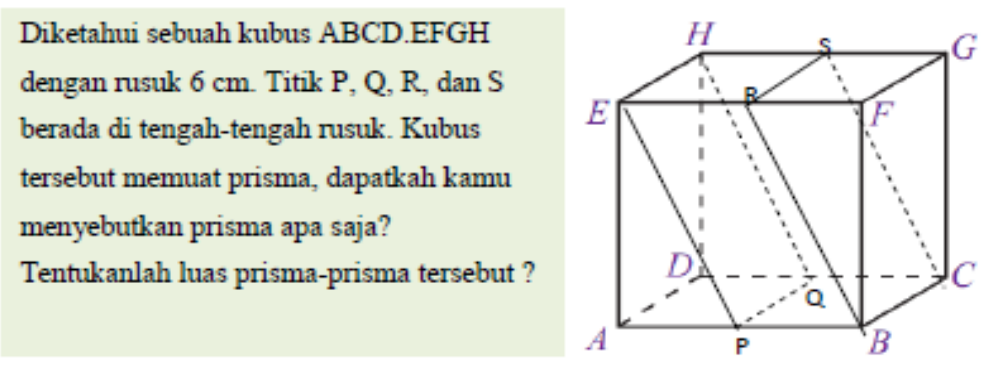

Gambar 4. Kubus ABCD.EFGH

dan $\mathrm{BR}$, yang memerlukan pengetahuan awal teorema Pythagoras. Awalnya siswa mengalami kesulitan namun setelah guru memberikan scaffolding bahwa segitiga yang memuat sisi EP adalah segitiga siku-siku siswa dapat dengan mudah menentukan panjangnya sisi EP.

Masalah masih muncul ketika siswa harus menunjukkan sisi-sisi mana saja yang membatasi prisma yang terbentuk. Melihat kondisi yang cukup menyita banyak waktu, akhirnya guru memandu siswa melalui $L C D$ dan papan tulis untuk mengamati prisma yang terbentuk dan sisi-sisi mana saja yang membatasi. Guru tidak meminta siswa menghitung luas melainkan hanya mengidentifikasi sisi-sisi yang membatasi dan menentukan rumus luas prisma yang mereka temukan. Karena ada tiga buah prisma yang terbentuk, guru membagi prisma tersebut pada tiga kelompok baris kemudian salah seorang anggota kelompok menuliskan jawabannya di papan tulis.

Karena kendala waktu, pada bagian mengkonstruksi luas limas, hanya untuk jenis limas segitiga yang didiskusikan sedangkan limas segiempat siswa untuk mempelajari sendiri. Selanjutnya pembelajaran, guru membahas contoh soal pertama sedangkan yang kedua dibahas oleh masing-masing kelompok kemudian salah seorang siswa secara sukarela mempresentasikannya.

\section{Pertemuan ke-3}

Pembelajaran pertemuan ketiga mempelajari tentang volume limas, hampir sama dengan pembelajaran pada pertemuan kedua yaitu diawali dari masalah. Masalah yang dimunculkan adalah soal menentukan volume prisma yang ada di dalam sebuah kubus. Semua siswa sudah memahami tentang rumus volume prisma sehingga siswa dapat menyelesaikan masalah ini lebih cepat dan sesuai dengan alokasi waktu di RPP.

Pembelajaran selanjutnya siswa mendiskusikan bagaimana mengkonstruksi volume limas dari sebuah kubus dan prisma. Berdasarkan pengalaman pada pembelajaran sebelumnya, guru dalam memberikan scaffolding tidak banyak ke kelompok per kelompok. Demi efektifitas dan efisiensi waktu guru secara interaktif memberikan instruksi dari depan kelas, hingga pada akhirnya siswa menyimpulkan rumus volume prisma yang mereka peroleh. Pada pertemuan ketiga ini, manajamen waktu dapat lebih terkontrol, namun peran siswa dalam berdiskusi kelompok berkurang karena guru lebih banyak memandu. Hal ini berdasarkan pengamatan guru siswa cukup sulit untuk membangun pemahaman mereka secara mandiri.

\section{PENUTUP}

Dari uraian hasil penelitian di atas dapat disimpulkan bahwa perangkat pembelajaran yang digunakan pada pembelajaran sebelumnya belum dapat menggali kemampuan penalaran matematis. Kemudian, desain didaktis yang dikembangkan dapat memperkecil gap yang dihadapi siswa. Kemampuan penalaran matematis siswa meningkat terlihat dari berkurangnya kesulitan-kesulitan yang di alami siswa dalam menyelesaikan soal penalaran matematis pada materi luas dan volume limas desain didaktis di kembangkan. Kebanyakan siswa memberikan tanggapan yang positif terhadap desain didaktis yang dikembangkan.

\section{DAFTAR PUSTAKA}

Adams R \& Wu M. 2000. PISA 2000 Technical Report. Organisation for Economic Co-operation and Development (OECD). 
Brousseau, G. (2002). Theory of Didactical Situation in Mathematics. Dordrecht: Kluwer Academic Publishers.

Burger, W.F. \& Shaugnessy, M.J. (1986). Characterizing the van Hiele Levels of Development in Geom etry. Journal for Research in Mathematics Education, 17(1), 31-48.

Halat, E., Jakubowski, E., \& Aydin, N. (2008). Reformbased curriculum and motivation in geometry. Eurasia Journal of Mathematics, Science and

Technology Education, 4(3), 285-292.

Herman, T. (2007). Pembelajaran Berbasis Masalah untuk Meningkatkan Kemampuan Berpikir Matematis Tingkat Tinggi Siswa Sekolah Menengah Pertama. Jurnal Educationist, 1(1), 47-56.

Sumarmo, U dan Permana, Y. (2007). Mengembangkan Kemampuan Penalaran dan Koneksi Matematik Siswa SMA Melalui Pembelajran Berbasis Masalah. Jurnal Educationist, 1(2), 116-123.

Supriatna. (2011). Pengembangan Bahan Ajar Matematika Pemecahan Masalah pada Luas Daerah Segitiga.
Suryadi. D. (2010). Menciptakan Proses Belajar Aktif: Kajian dari Sudut Pandang Teori Belajar dan Teori Didaktik, Didi Suryadi Official Website. http:// didi-suryadi.staf.upi.edu/files/2011/06/MENCIPTAKAN-PROSES-BELAJAR-AKTIF.pdf (diunduh 20 Desember 2011).

Suryadi, D. (2011). Didactical Design Research (DDR) dalam Pengembangan Pembelajaran Matematika. Didi Suryadi Official Website. http://didi-suryadi.staf.upi.edu/files/2011/06/DIDACTICAL-DESIGN-RESEARCH-DDR.pdf (diunduh 4 Januari 2012).

Suwaji, U.T. (2008). Permasalahan Pembelajaran Geometri Ruang SMP dan Alternatif Pemecahannya. P4TKM Yogyakarta: Depdiknas.

Thompson, J. (2006). Assessing Mathematical Reasoning: An Action Research Project. Michigan State University Official Website https://www.msu. edu/ thomp6o3/assess\%2oreasoning.pdf (diunduh 13 Desember 2011).

Warkitri, dkk. (1990). Penilaian Pencapaian Hasil Belajar. Jakarta: Karunika UT. 